In a letter to the undersigned, Mr. Field writes that this mimeographed report is considered to be only a first draft of a more finished publication. Clearly some of the data obtained, although chiefly compiled from published works, must be considered tentative. To illustrate the immense amount of work which has gone to make up this publication, Part ro includes no less than 48 separate maps.

Seeing that any subsequent publication on the same lines is not likely to appear for several years, the whole work, which was received in nine jackets, has been bound in 4 volumes for the Society's library, Vol. I consisting of Parts I and 2a, Vol. 2 Parts 2b-4, and Vol. 3 Parts 5-I0. Vol. 4 is a very comprehensive index.

Distribution has been very limited. In Great Britain, in addition to the Society's copy of the report, only the Scott Polar Research Institute and the Royal Geographical Society have received copies.

In his letter Mr. Field writes that he will welcome comment and criticism. He wishes "to be notified of any errors or omissions so that errata sheets may be noted and new sources of information kept on file. Such information will be of help to anyone who in future may consult the report or use it as a basis for assembling a more complete and up-to-date account." In this connexion there is one criticism I have to make. The compilers have obviously been in some difficulty in settling the title of the work. In the introduction its scope is defined as "concerned primarily with the location, distribution, characteristics, behaviour and significance of existing mountain glaciers". Since the operative word is "existing" the use of the word "glaciation" in the title is thus not desirable.

In 1954 there was an editorial note in this Journal, Vol. 2, No. I6, I954, p. 378, advocating the use of the words "glacierization", "ice-cover" or "glacier-cover" for existing glaciers and ice sheets, and urging that the word "glaciation" should be used only in the sense of "land formerly under ice". Of the eight letters published in the ensuing correspondence (ibid., p. 507-09) only one dissented from this distinction.

It is true that in this work there is brief reference to glacial geology and to one or two subjects not purely glaciological, but these constitute only a very minor part of the work. I suggest that a more suitable title would be "The mountain ice cover of the Northern Hemisphere".

Finally I want to accord the greatest credit to Mr. Field and his many helpers for bringing together and compiling so many data from such widely separated regions.

G. Seligman

\title{
OBITUARY
}

\section{RUDOLF STREIFF-BECKER-I873-I959}

Rudolf Streiff was born on 19 May 1873 in Vienna. After the death of his father, who was an engineer, his mother returned to her home town in Switzerland. Here in the house of his grandfather Rudolf passed a happy youth in very simple surroundings. While at school he had already shown considerable artistic talent. As his wish to become a naturalist appeared to his mother to promise an uncertain career, he went to the Technical College in Winterthur to become an engineer.

In 1894 Streiff left his home in order to emigrate to Brazil. With considerable endurance and untiring industry he was able, together with his younger brother, to build up a sound and promising business in a few years; this remained under his management for two decades.

After his return in I9I9 with his family, he was able to fulfil the dream of his youth of becoming an investigator into the problems of nature. His principal interests were the föhn 
and the flow of glaciers. As a keen mountaineer he had many opportunities of carrying out observations and measurements on glaciers, which he was able to continue in later years. From I 922 onwards many publications on these subjects appeared in his name, as is well known to readers of the Fournal of Glaciology. In a rough list I have compiled I find that at least thirty-two papers appeared under his name in the years 1922-1957.

In r 940 he was made an Honorary Member of the Naturforschende Gesellschaft of the Canton Glarus. He was also an Honorary Member of the Glacier Commission of the Schweizerische Naturforschende Gesellschaft; he was also one of the keenest members of the Zürcher Gletscher Kommision.

All who had the good fortune to come into contact with his delightful personality, and his enthusiasm for everything that was true and good, will always hold his memory in honour.

R. Haefeli

\section{NOAH ERNEST DORSEY-I873-1959}

Dr. N. ERnest Dorsey, who died at Towson, Maryland, on 6 July r 959 at the age of 86, will be known by name to all scientists who have worked on the properties of ice or water as the author of their standard reference book Properties of ordinary water-substance, a book which, although published twenty years ago, is still the main available reference book for glaciologists who want to find out what is known about some of the less familiar properties of ice. Dr. Dorsey graduated from Johns Hopkins University in his native state of Maryland, and after a short period teaching at that University and a couple of years with the Department of Agriculture, he joined the National Bureau of Standards in 1903, and remained there, apart from a few years of private consulting work in the twenties, until his retirement in 1943. He made many investigations in electricity, heat and light, and also served as an associate editor of the International Critical Tables. Even after retirement he remained active, as several published papers bear witness.

J. W. Glen

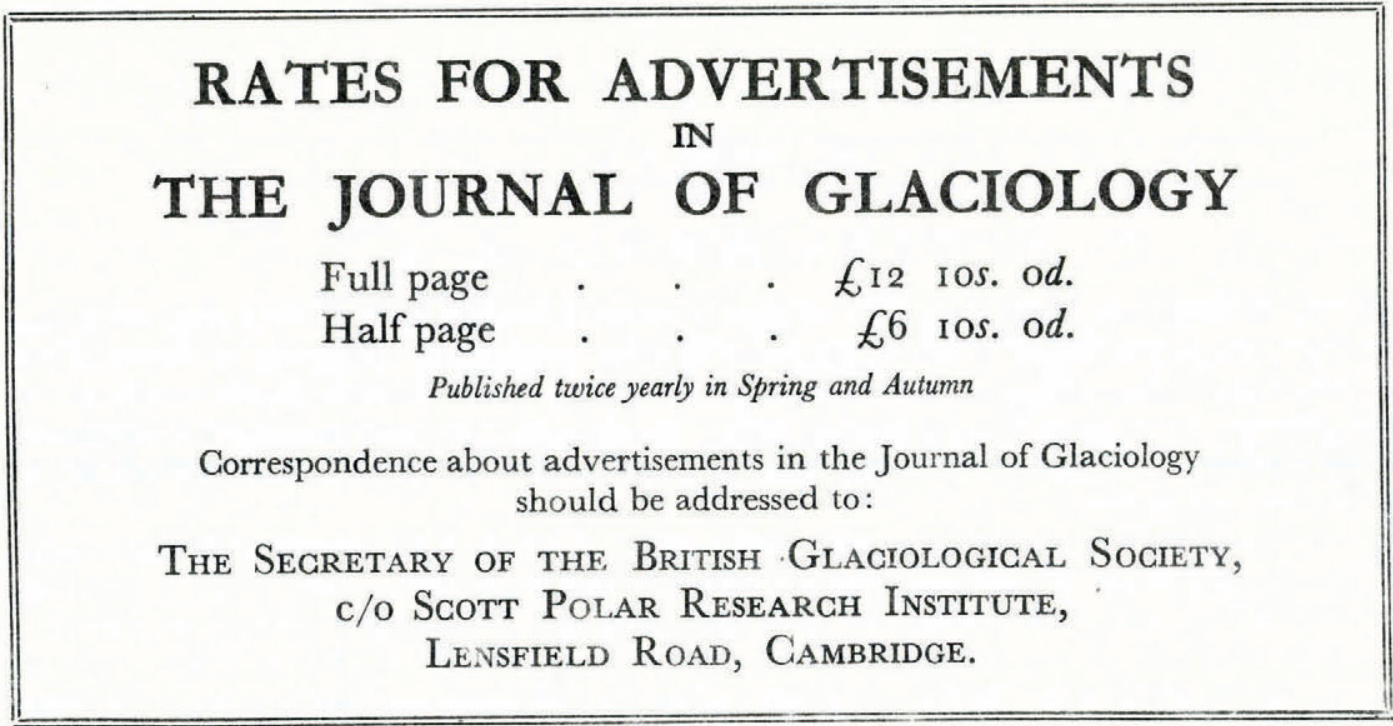

